\title{
Native and Phosphorylated Bovine Adrenal Tyrosine 3-Monooxygenase. Interactions with Tetrahydropterins and Substrate and Stability of the Formed 4a-Hydroxy-Tetrahydrobiopterin
}

\author{
By Jan Haavik*, Kristoffer K. Andersson, Torgeir Flatmark \\ Department of Biochemistry, University of Bergen, Årstadveinen, 19, N-5009 Bergen, Norway \\ Leif Petersson
}

Department of Biophysics, University of Stockholm, S-10691 Stockholm, Sweden

(Received May 1988)

\section{Summary}

The catalytic activity of tyrosine 3-monooxygenase (tyrosine hydroxylase) is dependent on a tetrahydropterin cofactor and ezyme-bound iron. The oxidation of tetrahydrobiopterin by bovine adrenal tyrosine hydroxylase was studied by high performance liquid chromatography (HPLC). The first pterin product detected during catalytic turnover, 4a-hydroxy-tetrahydrobiopterin, was isolated by HPLC and the pseudo first-order rate constant of its dehydration to quinonoid dihydrobiopterin was estimated. The $t_{1 / 2}$ was found to be 45 and $72 \mathrm{~s}$ in 100 and $5 \mathrm{mmol} / \mathrm{L}$ Tris- $\mathrm{HCl}$, respectively, at $\mathrm{pH} 7.5$ and $23^{\circ} \mathrm{C}$.

The rate of the 4a-hydroxy-tetrahydropterin formation was found to increase on phosphorylation of the enzyme by cyclic AMP-dependent protein kinase. The phosphorylation did not significantly change the electron paramagnetic resonance (EPR) spectrum of tyrosine hydroxylase. However, in the presence of substrate or cofactor and dithiothreitol, the EPR spectral properties were strikingly different from those observed prior to phosphorylation. Our findings are in accordance with a mechanism in which the covalently bound phosphate activates the enzyme by facilitating changes in the redox-state of the enzyme-bound iron.

\section{Introduction}

The most well-defined biological role of tetrahydropterins in mammals is their function as electron donors in the monooxygenase reactions catalyzed by the three aromatic amino acid hydroxylases, i. e. phenylalanine, tyrosine and tryptophan hydroxylase (for reviews, see refs. 1-3). These enzymes show a high degree of

\footnotetext{
* Author to whom correspondence should be addressed Enzymes: Tyrosine 3-monooxygenase, tyrosine hydroxylase (EC 1.14.16.2); Phenylalanine 4-monooxygenase, phenylalanine hydroxylase (EC 1.14.16.1).

Abbreviations: $\mathrm{BH}_{4}, 6(R)$-tetrahydrobiopterin; $4 \mathrm{a}-\mathrm{OH}-\mathrm{BH}_{4}, 4 \mathrm{a}$ hydroxy-tetrahydrobiopterin; $\mathrm{qBH}_{2}$, quinonoid dihydrobiopterin; 7,8- $\mathrm{BH}_{2}, 7,8$-dihydrobiopterin; 6- $\mathrm{MPH}_{4}$, 6-methyltetrahydropterin; q6- $\mathrm{MPH}_{2}$, quinonoid 6-methyldihydropterin; DOPA, 3,4-dihydroxy-phenylalanine; DTT, dithiothreitol; EPR, electron paramagnetic resonance; HPLC, high-performance liquid chromatography.
}

sequence homology and are postulated to have similar reaction mechanisms $(1-4)$. During catalytic turnover, tetrahydropterins are oxidized to dihydropterins in the tyrosine hydroxylase reaction $(1-3,5)$, e. $g$.

$$
\begin{gathered}
\text { L-Tyrosine }+\mathrm{BH}_{4}+\mathrm{O}_{2} \stackrel{\mathrm{k}_{1}}{\rightarrow} \mathrm{DOPA}+4 \mathrm{a}-\mathrm{OH}-\mathrm{BH}_{4} \\
4 \mathrm{a}-\mathrm{OH}-\mathrm{BH}_{4} \stackrel{\mathrm{k}_{2}}{\rightarrow} \mathrm{qBH}_{2}+\mathrm{H}_{2} \mathrm{O} \\
\mathrm{qBH}_{2} \stackrel{\mathrm{k}_{3}}{\rightarrow} 7,8-\mathrm{BH}_{2}
\end{gathered}
$$

The formed dihydrobiopterins $\left(\mathrm{qBH}_{2}\right.$ and $\left.7,8-\mathrm{BH}_{2}\right)$ can in turn be regenerated to tetrahydrobiopterin $\left(\mathrm{BH}_{4}\right)$ by dihydropteridine reductase and dihydrofolate reductase, respectively (2). Although the overall stoichiometry of the hydroxylation reaction (equation 1 ) is known, the precise function of the tetrahydrop- 
terins in the catalytic cycle is still unclear. In addition to their function as electron donors in the reduction of dioxygen, tetrahydropterins may also activate the enzyme, as observed for phenylalanine hydroxylase, in which the catalytically inactive $\mathrm{Fe}$ (III) bound to the enzyme appears to be reduced by the cofactor $2,5,6)$.

Like phenylalanine hydroxylase, bovine adrenal tyrosine hydroxylase also contains substantial amounts of high-spin $\mathrm{Fe}(\mathrm{III})(7,8)$. However, in contrast to phenylalanine hydroxylase, recent studies on this enzyme (8) have revealed that tetrahydropterins reduce only a minor fraction of the $\mathrm{Fe}(\mathrm{III})$ present in the enzyme as isolated. Since a phosphorylated form of tyrosine hydroxylase has a more favorable $K_{\mathrm{m}}$-value for its cofactor, and possibly also an increased $V_{\max }{ }^{-}$ value $(1,9)$, we have now further examined the reactions of the phosphorylated enzyme with the cofactor and the substrate.

\section{Materials and Methods}

Tyrosine hydroxylase was purified from the cytosolic fraction of bovine adrenal medulla homogenates, using a new large-scale procedure (8). Analyses of the phosphate content of various enzyme samples, prepared by this procedure, have shown the presence of somewhat varying amounts of phosphate, i.e. from below 0.2 to approx. $0.6 \mathrm{~mol}$ phosphate per mol monomer (8). The enzyme preparations used in the present study had specific activities of about 400 $\mathrm{nmol} /(\mathrm{min} \cdot \mathrm{mg})$ when assayed at $\mathrm{pH} 6.0$, using $1 \mathrm{mmol} / \mathrm{L}$ 6-methyltetrahydropterin $\left(6-\mathrm{MPH}_{4}\right)$ as the cofactor and $0.3 \mathrm{mmol} / \mathrm{L}$ L-tyrosine as the substrate (10).
In the experiments using phosphorylated hydroxylase, the enzyme $(1.5 \mathrm{~g} / \mathrm{L})$ was incubated with $0.1 \mathrm{~g} / \mathrm{L}$ of the catalytic subunit of bovine heart cyclic AMPdependent protein kinase (11), $4 \mathrm{mmol} / \mathrm{L} \mathrm{MgCl}_{2}$, $1 \mathrm{mmol} / \mathrm{L}\left[{ }^{32} \mathrm{P}\right] \mathrm{ATP}, 20 \mu \mathrm{mol} / \mathrm{L}$ dithiothreitol (DTT), $100 \mathrm{mmol} / \mathrm{L} \mathrm{KCl}$ and $4 \%(\mathrm{w} / \mathrm{v})$ sucrose in $75 \mathrm{mmol} / \mathrm{L}$ $\mathrm{K}$-phosphate, $\mathrm{pH}$ 7.0. After a reaction time of $15 \mathrm{~min}$ at $30^{\circ} \mathrm{C}$, the enzyme was subjected to gel filtration on a Sephadex G-25 column equilibrated with 200 $\mathrm{mmol} / \mathrm{L} \mathrm{KCl}$ in $100 \mathrm{mmol} / \mathrm{L} \mathrm{K}$-phosphate. Under these conditions, $0.6-0.8 \mathrm{~mol}$ phosphate per mol enzyme monomer was found to be incorporated into tyrosine hydroxylase (12). Thus, after phosphorylation, the enzyme contained at least $0.8 \mathrm{~mol}$ phosphate per mol monomer. In control experiments, the enzyme was incubated (without added ATP) and gel filtered under identical conditions.

Phenylalanine hydroxylase was purified from bovine liver by a slight modification (13) of the procedure of Shiman et al. (14).

$6(R)-\mathrm{BH}_{4}$ and $6(R S)$-methyltetrahydropterin $\mathrm{MPH}_{4}$ ) were from Dr. B. Schircks Laboratories (Jona, Switzerland). 4a-hydroxy-tetrahydrobiopterin (4a$\left.\mathrm{OH}-\mathrm{BH}_{4}\right)$ was prepared by incubation of $50 \mu \mathrm{mol} / \mathrm{L}$ $6(R)-\mathrm{BH}_{4}$ with $20 \mu \mathrm{mol} / \mathrm{L}$ phenylalanine hydroxylase, $1 \mathrm{mmol} / \mathrm{L}$ dithiothreitol, $1 \mathrm{mmol} / \mathrm{L}$ phenylalanine, 0.2 $\mathrm{g} / \mathrm{L}$ catalase and $100 \mathrm{mmol} / \mathrm{L}$ Tris- $\mathrm{HCl}, \mathrm{pH} 8.4$ (15). The enzyme was activated by incubation with $2 \mathrm{mmol} / \mathrm{L} \mathrm{L}$-phenylalanine at $25^{\circ} \mathrm{C}$ for $2 \mathrm{~min}$ before the reaction was started by addition of cofactor. After a reaction time of $2 \mathrm{~min}$ at $25^{\circ} \mathrm{C}$, a $20 \mu \mathrm{L}$ aliquot of the mixture was injected into the liquid chromatograph and the peak corresponding to the $4 \mathrm{a}-\mathrm{OH}-\mathrm{BH}_{4}$ was collected at $-80^{\circ} \mathrm{C}$ (Fig. 1). Due to the rapid

\begin{tabular}{|c|c|c|c|}
\hline Incubation & Separation & Detection & Isolation \\
\hline \multicolumn{4}{|l|}{$\begin{array}{l}\text { Tyrosine/ } \\
\text { Phenylalanine } \\
\text { hydroxylases }\end{array}$} \\
\hline $\begin{array}{c}+ \\
\text { Tetrahydropterins } \\
+\end{array}$ & $\begin{array}{l}\text { Immediate injection } \\
\text { into a } \mathrm{G}_{8} \\
\text { reversed phase } \\
\text { high-speed } \\
\text { HPLC column }\end{array}$ & $\begin{array}{l}\text { Diode array } \\
\text { rapid scanning } \\
\text { UV-detector }\end{array}$ & $\begin{array}{l}\text { Collection at } \\
-80 \mathrm{OC} \\
\text { Storage in } \\
\mathrm{N}_{2} \text { (liq) }\end{array}$ \\
\hline \multicolumn{4}{|l|}{ Substrates } \\
\hline $0-120 \mathrm{~s}$ & $20-60 \mathrm{~s}$ & $10 \mathrm{~ms}$ & several weeks \\
\hline
\end{tabular}

Figure 1. Generation and isolation of tetrahydropterin oxidation products. For further details, see the main text. 
decay of the 4a-hydroxy-tetrahydropterins, carefully controlled incubation time and temperature was necessary in order to obtain reproducible results.

HPLC analysis of pterins was performed on a Hewlett-Packard $60 \times 4.6 \mathrm{~mm}$ i.d. $(3 \mu \mathrm{m}$ particle size $) \mathrm{C}_{18}$ reversed phase column, equipped with a $30 \times 4.6 \mathrm{~mm}$ i. d. $C_{18}$ precolumn ( $5 \mu \mathrm{m}$ particle size) (15). The degassed mobile phase (ammonium acetate, ammonium formate, potassium phosphate or Tris- $\mathrm{HCl}$ ) was pumped at $2.0 \mathrm{~mL} / \mathrm{min}$. The eluant was monitored with a Hewlett-Packard model 1040A diode array HPLC detector (Fig. 1).

X-band EPR spectra at $9.24 \mathrm{GHz}$ microwave frequency were obtained with a Bruker ESP 300 EPR system equipped with an Oxford Instruments helium flow cryostat (ESR-9). The spectra of tyrosine hydroxylase $(2 \mathrm{~g} / \mathrm{L}$ in $150 \mu \mathrm{L})$ were obtained with $1 \mathrm{~mW}$ microwave power at $3.6 \mathrm{~K}, 10$ Gauss field modulation and $11 \mathrm{~min}$ sweep time. The samples (in $200 \mathrm{mmol} / \mathrm{L}$ $\mathrm{KCl}$ and $100 \mathrm{mmol} / \mathrm{L} \mathrm{K}$-phosphate, $\mathrm{pH} \mathrm{7.0)} \mathrm{were}$ kept in EPR tubes (i. d. $=4 \mathrm{~mm}$ ); incubation of the enzyme with substrate or $6-\mathrm{MPH}_{4}$ and DTT was performed for $1 \mathrm{~min}$ at $25^{\circ} \mathrm{C}$, and the samples were subsequently frozen in ethanol kept at $-80^{\circ} \mathrm{C}$ and stored in liquid nitrogen.

\section{Results}

Kinetics of conversion of 4a-hydroxy-tetrahydropterins to dihydropterins

The 4a-hydroxy-tetrahydropterin has recently been isolated and established as an immediate reaction product of both the phenylalanine and tyrosine hydroxylase reactions with both the naturally occurring and synthetic tetrahydropterins $(2,5,15,16)$. The formation of the 4a-hydroxy-tetrahydropterins by tyrosine hydroxylase (or phenylalanine hydroxylase) can be selectively measured using high-speed HPLC with UV-detection (15). The 4a-hydroxy-tetrahydropterins are, however, rapidly dehydrated to the quinonoid dihydropterins in a spontaneous $(2,16,17)$ or enzyme catalyzed $(2,17)$ reaction (equation 2 ).

Using preparative high-speed HPLC, the enzymatically generated $4 \mathrm{a}-\mathrm{OH}-\mathrm{BH}_{4}$ was isolated and stored at $-80{ }^{\circ} \mathrm{C}(15)$. Its spontaneous decay to $\mathrm{qBH}_{2}$ (equation 2) and the subsequent tautomerization to 7,8$\mathrm{BH}_{2}$ (equation 3) was followed selectively (Fig. 2A). The pseudo first-order rate constant $\left(k_{2}\right.$ in equation 2 ) of the non-enzymatic dehydration of the $4 \mathrm{a}-\mathrm{OH}$ $\mathrm{BH}_{4}$ in Tris- $\mathrm{HCl}, \mathrm{pH} 7.5$, was found to be slightly dependent on the ionic strength. Thus, the observed $t_{1 / 2}$ at $23{ }^{\circ} \mathrm{C}$ was approx. $1.2 \mathrm{~min}$ in $5 \mathrm{mmol} / \mathrm{L}$ Tris-
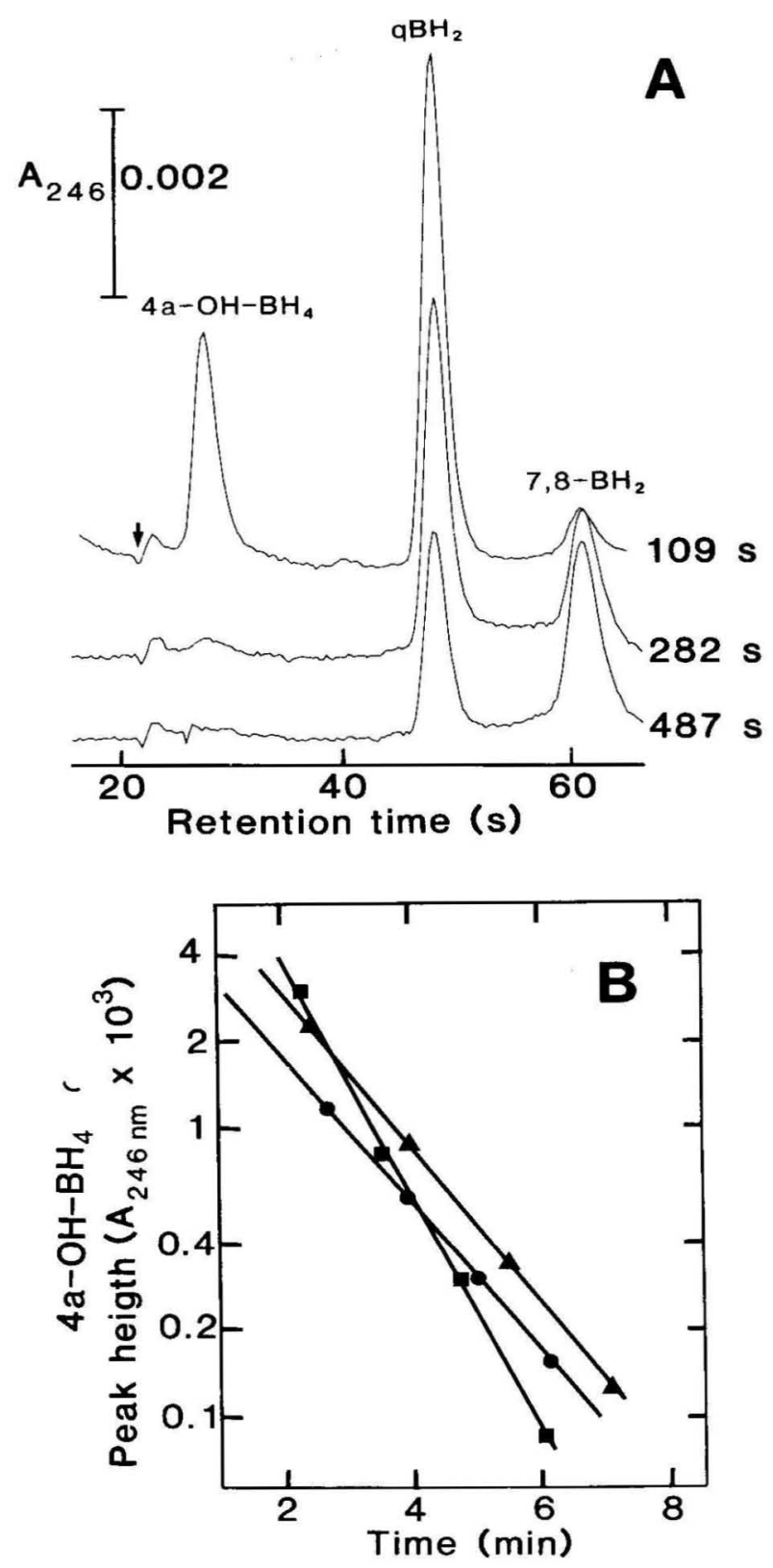

Figure 2. Nonenzymatic conversion of $4 \mathrm{a}-\mathrm{OH}-\mathrm{BH}_{4}$ to $\mathrm{qBH}_{2}$ and $7,8-\mathrm{BH}_{2}$ in Tris- $\mathrm{HCl}, \mathrm{pH} 7.50$, at $23^{\circ} \mathrm{C}$. (A) $4 \mathrm{a}-\mathrm{OH}-\mathrm{BH}_{4}$, prepared as described in the Methods section, was incubated for $81 \mathrm{~s}-459 \mathrm{~s}$ in $100 \mathrm{mmol} / \mathrm{L}$ Tris- $\mathrm{HCl}$ before injection into the liquid chromatograph. During incubation and chromatography, the $4 \mathrm{a}-\mathrm{OH}-\mathrm{BH}_{4}$ was gradually converted into $\mathrm{qBH}_{2}$ and $7,8-\mathrm{BH}_{2}$. The traces represent the absorbance at $246 \mathrm{~nm}$. The solvent front appears at $22 \mathrm{~s}$ (vertical arrow). The total incubation time (including retention time) is also indicated. (B) Pseudo first-order reaction kinetics for the conversion of $4 \mathrm{a}$ $\mathrm{OH}-\mathrm{BH}_{4}$ to the $\mathrm{qBH}_{2}$ on incubation at $23{ }^{\circ} \mathrm{C}$ in $5 \mathrm{mmol} / \mathrm{L}(\bullet)$, $20 \mathrm{mmol} / \mathrm{L}(\boldsymbol{\Delta})$ or $100 \mathrm{mmol} / \mathrm{L} \mathrm{( \square )} \mathrm{Tris-HCl,} \mathrm{pH} 7.50$.

$\mathrm{HCl}, 1.1 \mathrm{~min}$ in $20 \mathrm{mmol} / \mathrm{L}$ Tris- $\mathrm{HCl}$ and $45 \mathrm{~s}$ in 100 $\mathrm{mmol} / \mathrm{L}$ Tris (Fig. 2B). For comparison, the observed $t_{1 / 2}$ was approx. $40 \mathrm{~s}$ in both $20 \mathrm{mmol} / \mathrm{L}$ ammonium formate, $\mathrm{pH} 7.5$, or $20 \mathrm{mmol} / \mathrm{L} \mathrm{K}$-phosphate, $\mathrm{pH} 7.5$. 
The effect of cyclic AMP-dependent phosphorylation of tyrosine hydroxylase on the formation of $4 \mathrm{a}-\mathrm{OH}$ $\mathrm{BH}_{4}$

The phosphorylation of tyrosine hydroxylase by cyclic AMP-dependent and other protein kinases is known to stimulate its catalytic activity (for a review, see ref. 1). These studies have all been based on the assay of DOPA as the product of the tyrosine hydroxylase reaction. Using assay conditions which favour the accumulation of 4a-hydroxy-tetrahydropterins (1518), a close correlation has been observed between the amount of 4a-hydroxy-tetrahydropterins recovered by HPLC and the amount of tyrosine formed (15). From Figure 3 it is seen that the $4 \mathrm{a}-\mathrm{OH}-\mathrm{BH}_{4}$ formation by tyrosine hydroxylase phosphorylated by the purified catalytic subunit of bovine cyclic AMPdependent protein kinase, is increased about five-fold compared to the non-phosphorylated control enzyme. Under these conditions a similar increased formation of tyrosine from phenylalanine was also observed (data not shown).

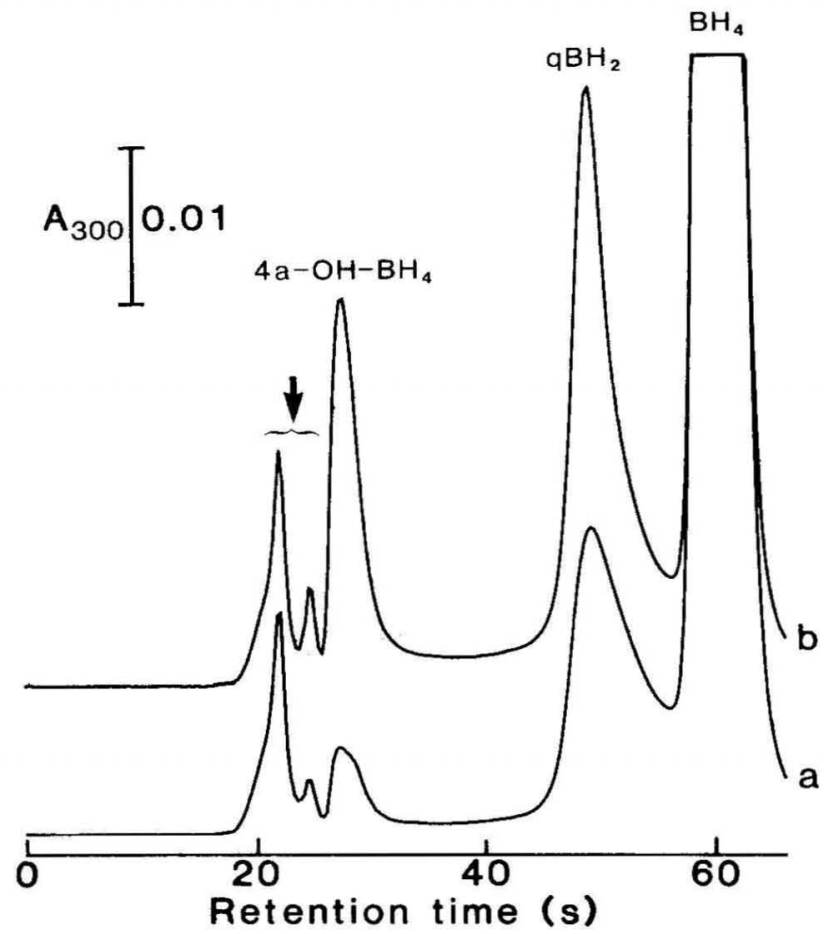

Figure 3. The effect of phosphorylation of tyrosine hydroxylase on the formation of $4 \mathrm{a}-\mathrm{OH}-\mathrm{BH}_{4}$ and $\mathrm{qBH}_{2}$. Unphosphorylated (trace a) or phosphorylated (trace b, upper trace) tyrosine hydroxylase $(2 \mathrm{~g} / \mathrm{L})$ was incubated with $0.5 \mathrm{mmol} / \mathrm{L} \mathrm{BH}_{4}$ in the presence of $1 \mathrm{mmol} / \mathrm{L} \mathrm{DTT,} 2 \mathrm{mmol} / \mathrm{L} \mathrm{L}$-phenylalanine, $0.2 \mathrm{~g} / \mathrm{L}$ catalase and $100 \mathrm{mmol} / \mathrm{L}$ Tris- $\mathrm{HCl}, \mathrm{pH} 8.4$. After incubation for $2 \mathrm{~min}$ at $25^{\circ} \mathrm{C}$, a $20 \mu \mathrm{l}$ aliquot was injected into the liquid chromatograph, and the absorbance was measured at $300 \mathrm{~nm}$. The vertical arrow indicates components of the incubation mixture (Tris and ATP) eluting at or shortly after the solvent front.
Phosphorylation of tyrosine hydroxylase facilitates changes in the EPR spectrum of the enzyme-bound $\mathrm{Fe}($ III $)$

Tyrosine hydroxylase as isolated contains $0.6-0.9$ mol Fe per mol subunit enzyme. Its EPR spectrum shows that the enzyme-bound $\mathrm{Fe}$ (III) has g-values around 7.0, 5.2 and 1.9. This set of $g$-values is typical of high-spin $\mathrm{Fe}(\mathrm{III})$ species in an environment of slightly distorted axial symmetry $(E / D \sim 0.04$ $\pm 0.01)$. On addition of L-tyrosine this EPR signal is virtually unchanged (8). Under aerobic conditions the presence of an excess of $6-\mathrm{MPH}_{4}(0.2 \mathrm{mmol} / \mathrm{L})$ plus DTT $(2 \mathrm{mmol} / \mathrm{L})$ induces moderate changes of the EPR spectra, even in the presence of L-tyrosine, while the addition of a strong reducing agent such as dithionite $(10 \mathrm{mmol} / \mathrm{L})$, makes the iron EPR silent, indicating that the iron is reduced to $\mathrm{Fe}(\mathrm{II})(8)$.

Figure 4 shows the effect of phosphorylation on the EPR spectrum of tyrosine hydroxylase, in the presence of either substrate or cofactor and DTT. While phosphorylation itself has small effects on the EPR

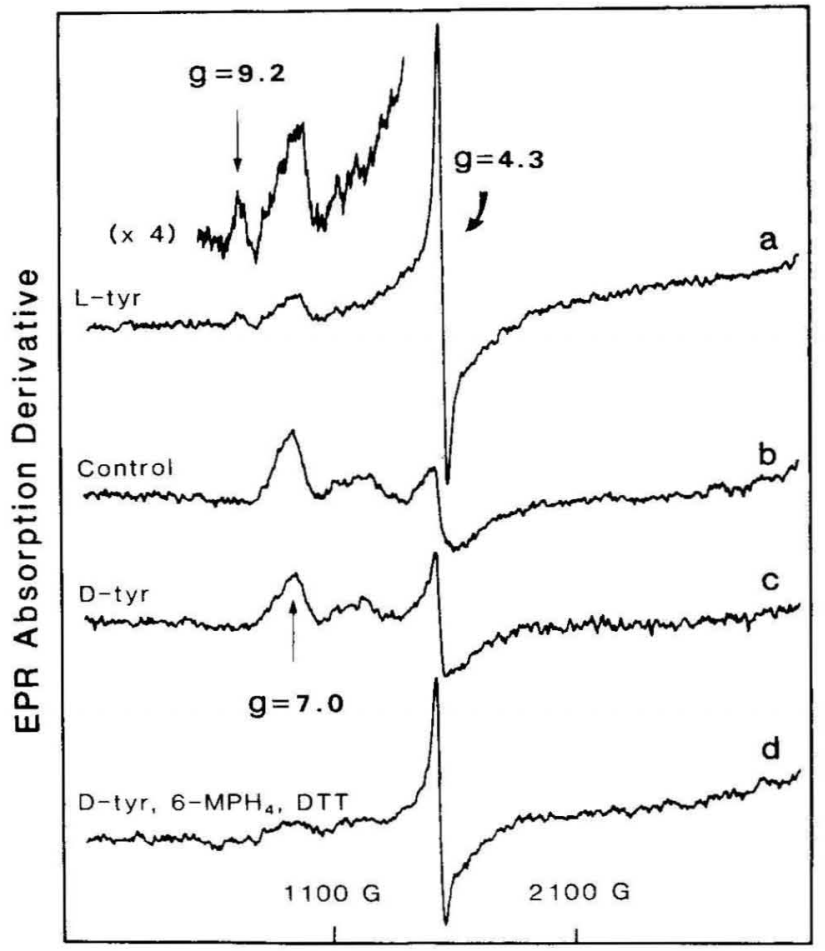

Figure 4. EPR spectra of phosphorylated tyrosine hydroxylase (a) After incubation with $1.5 \mathrm{mmol} / \mathrm{L}$ L-tyrosine, (b) only standard incubation medium (control), (c) after incubation with $1.7 \mathrm{mmol} / \mathrm{L} \mathrm{D}$-tyrosine, and (d) after incubation with $1 \mathrm{mmol} / \mathrm{L}$ 6- $\mathrm{MPH}_{4}, 1.7 \mathrm{mmol} / \mathrm{L}$ D-tyrosine and $5 \mathrm{mmol} / \mathrm{L}$ DTT. All incubations were performed for $1 \mathrm{~min}$ at $25^{\circ} \mathrm{C}$. The spectra are not corrected for the small dilution upon adding substrate or cofactor $(7 \%$ dilution in Figs. $4 \mathrm{a}$ and $4 \mathrm{c}, 9 \%$ dilution in Fig. 4d); $\mathrm{pH}$ was kept between 7.0 and 7.2 . 
spectrum of the resting enzyme (Fig. 4b), the spectrum in the presence of either substrate or cofactor and DTT is markedly changed by phosphorylation. Thus, after incubation with $1.5 \mathrm{mmol} / \mathrm{L}$ L-tyrosine (Fig. 4a), the signal intensity of the species with $g_{\max }$ around 7.0 was significantly reduced. A new high-spin Fe(III) species with a $g_{\max }$-value of 9.2 appeared, and the contribution around $g=4.3$ was considerably increased. In comparison, incubation of the phosphorylated enzyme with $1.7 \mathrm{mmol} / \mathrm{L}$ D-tyrosine resulted in an EPR spectrum (Fig. 4c) which was similar to that of the phosphorylated enzyme control (Fig. 4b). Aerobic incubation with $2 \mathrm{mmol} / \mathrm{L} 6-\mathrm{MPH}_{4}$ and 10 $\mathrm{mmol} / \mathrm{L}$ DTT makes the previously EPR detectable Fe(III) with $g_{\max } \sim 7.0$ of the phosphorylated enzyme EPR silent, presumably due to reduction of its ferric iron to $\mathrm{Fe}$ (II) (12). This reduction is slightly influenced by the presence of D-tyrosine (Fig. 4d). In comparison, if the non-phosphorylated enzyme is incubated with $2 \mathrm{mmol} / \mathrm{L} 6-\mathrm{MPH}_{4}$ and $10 \mathrm{mmol} / \mathrm{L}$ DTT, more than $75 \%$ of the $g_{\max } \sim 7.0$ species is still present (data not shown).

\section{Discussion}

High-speed liquid chromatography as an analytical tool in the analysis of unstable tetrahydropterins

During catalytic turnover, both phenylalanine and tyrosine hydroxylase oxidize the tetrahydropterin cofactors, like tetrahydrobiopterin, tetrahydroneopterin and 6-methyl-tetrahydropterin, to their respective 4ahydroxy-tetrahydropterins (equation 1) (15). These compounds have previously been observed spectroscopically as transient intermediates $(2,15-18)$ or analyzed at subzero temperatures $(2,19)$. Thus, stopped-flow spectroscopy has provided valuable information about the kinetics and spectral properties of such intermediates formed in the phenylalanine and tyrosine hydroxylase reactions $(15,18)$. In order to obtain additional spectral and kinetic information about the oxidation of the cofactor in these reactions, we have developed a HPLC method for the spectroscopic characterization, quantitation and isolation of the unstable pterins formed in the enzymatic reactions (15). Thus, the HPLC analysis of pteridines $(20,21)$ has been extended to include also short-lived pterins. In the present study, this technique has been used to examine the spontaneous dehydration of $4 \mathrm{a}-\mathrm{OH}-\mathrm{BH}_{4}$. The rate of dehydration of 4a-hydroxy-tetrahydropterins ( $k_{2}$ in equation 2$)$ has been estimated spectroscopically for the synthetic $\mathrm{BH}_{4}$ analogue 6- $\mathrm{MPH}_{4}$ in a complex reaction mixture $(2,17)$. For the biopterin derivative, however, the rate of tautomerization of the quinonoid intermediate dihydropterin ( $k_{3}$ in equa- tion 3) is about 10 times faster, and this reaction therefore interferes in the estimation of the rate constant for the dehydration of $4 \mathrm{a}-\mathrm{OH}-\mathrm{BH}_{4}\left(k_{2}\right.$ in equation 2) under similar experimental conditions $(16,17)$. Using the rapid HPLC method, which separates the different pterins, the two sequential reactions can be studied separately (Fig. 2). The rate of disappearence of $4 \mathrm{a}-\mathrm{OH}-\mathrm{BH}_{4}\left(k_{2}\right.$ in equation 2$)$ was found to be only moderately influenced by the nature and concentration of the buffers employed. This is in contrast to the observed effects of buffer ions on the rate of tautomerization of the quinonoid dihydropterins $\left(k_{3}\right.$ in equation 3) (22).

\section{The role of iron in the tyrosine hydroxylase reaction}

Although iron seems to be essential for the catalytic activity of tyrosine hydroxylase, the mechanistic role of the enzyme-bound iron is not understood. The $\mathrm{Fe}$ (II) state seems to be catalytically important, since the enzyme is inhibited by low concentrations of $\mathrm{Fe}$ (II) chelators (8). This is analogous to phenylalanine hydroxylase and rat pheochromocytoma tyrosine hydroxylase, in which Fe(II) is postulated to be the only active iron species $(2,15,16)$. However, a considerable amount of the iron in tyrosine hydroxylase exists as Fe(III) (8), which has been studied by various spectroscopic techniques $(7,8,23)$. Thus, tyrosine hydroxylase as isolated has a blue-green colour $(7,8)$, and its resonance Raman spectra have been assigned to a coordination of the feedback inhibitors adrenaline and noradrenaline to the enzyme-bound highspin $\mathrm{Fe}$ (III) $(23,24)$. In analogy with studies on model complexes, evidence has been obtained in support of a catecholamine coordination which may lower the redox potential of the iron and thus stabilize the $\mathrm{Fe}(\mathrm{III})$ state $(12,23,24)$.

After phosphorylation, the Fe(III) species with $g_{\max }$ $\sim 7.0$ is made EPR-silent by incubation with 6- $\mathrm{MPH}_{4}$ and DTT (in the absence of added substrate), indicating that this $\mathrm{Fe}$ (III) species is reduced to Fe(II). The phosphorylation of tyrosine hydroxylase does not seem to change the reaction stoichiometry (equation 1), since a comparably increased formation of both $4 \mathrm{a}-\mathrm{OH}-\mathrm{BH}_{4}$ and tyrosine was observed and no new reaction products were detected. Similarly, the phosphorylated enzyme reacts in a strictly stereospecific manner with tyrosine, i. e. only the L-enantiomer (Fig. $4 \mathrm{a})$, as previously observed for the catalytic reaction $(1,15)$.

While tyrosine hydroxylase as isolated has many spectroscopic features which are distinct from those of phenylalanine hydroxylase, the phosphorylated enzyme shows some similarities to the non-phosphoryl- 
ated form of phenylalanine hydroxylase. For this enzyme, the direct formation of quinonoid dihydropterin is accompanied by the reduction of its $\mathrm{Fe}$ (III), in an activating reaction, which can be inhibited by catecholamines $(2,5,6)$. The molecular events responsible for the activation of tyrosine hydroxylase by phosphorylation (25) is presently not know. Our working hypothesis is that it decreases the affinity of the feedback inhibitors to the Fe(III) (Andersson, K. K. unpublished observations), thus facilitating changes in redox-state of the enzyme-bound iron (12, 24).

\section{Acknowledgement}

We are grateful for the expert technical assistance of Ms. S. E. Riise and Mr. T. Astlind. Prof. L. Que, Jr. and Dr. D. D. Cox are thanked for helpful discussions. This work was supported by The Norwegian Research Council for Science and the Humanities, Nordisk Industrifond, Nordiska Forskarkurser, the Nordic Insulin Foundation and a grant from the Swedish Natural Science Research Council to Prof. A. Ehrenberg.

\section{References}

1. Kaufman, S. \& Kaufman, E. E. (1985) in Folates and Pterins (R. L. Blakley and S. J. Benkovic, eds.) pp. $251-352$, John Wiley \& Sons., New York.

2. Shiman, R. (1985) in Folates and Pterins (R. L. Blakley and S. J. Benkovic, eds.) pp. 179-249, John Wiley \& Sons., New York.

3. Kuhn, D. M. \& Lovenberg, W. (1985) in Folates and Pterins (R. L. Blakley and S. J. Benkovic, eds.) pp. 353-399. John Wiley \& Sons., New York.
4. Grenett, H. E., Ledley, F. D., Reed, L. L. \& Woo, S. L. C. (1987) Proc. Natl. Acad. Sci. USA 84, 5530-5534.

5. Wallick, D. E., Bloom, L. M., Gaffney, B. J. \& Benkovic, S. J. (1984) Biochemistry 23, 1295-1302.

6. Marota, J. J. A. \& Shiman, R. (1984) Biochemistry 23, $1301-1311$.

7. Haavik, J., Andersson, K. K., Petersson, L. \& Flatmark, T. (1986) in Chemistry and Biology of Pteridines (B. A. Cooper and V. M. Whitehead, eds.) pp. $201-204$, Walter de Gruyter \& Co., Berlin, New York.

8. Haavik, J., Andersson, K. K., Petersson, L. \& Flatmark, T. (1988) Biochim. Biophys. Acta. 953, 142-156.

9. Richtand, N. M., Inagami, T., Misono, K. \& Kuczenski, R. (1985) J. Biol. Chem. 260, 8465-8473.

10. Haavik, J. \& Flatmark, T. (1980) J. Chromatogr. 198, 511 515 .

11. Reimann, E. M. \& Beham, R. A. (1983) Methods Enzymol. $99,51-55$

12. Andersson, K. K., Haavik, J., Flatmark, T. \& Petersson, L. (1988) Abstr. Commun. 14th Internat. Congr. Biochem., IUB, Prague, IV, 109.

13. Døskeland, A., Ljones, T., Skotland, T. \& Flatmark, T. (1982) Neurochem. Res. 7, 407-421.

14. Shiman, R., Gray, D. W. \& Pater, A. (1979) J. Biol. Chem. 254, 11300-11306

15. Haavik, J. \& Flatmark, T. (1987) Eur. J. Biochem. 168, $21-26$.

16. Dix, T. A., Kuhn, D. M. \& Benkovic, S. J. (1987) Biochemistry 26, 3354-3361.

17. Lazarus, R. A., Benkovic, S. J. \& Kaufman, S. (1983) J. Biol. Chem. 258, 10960-10962.

18. Haavik, J., Døskeland, A. P. \& Flatmark, T. (1986) Eur. J. Biochem. 160, 1-8.

19. Dix, T. A., Bollag, G. E., Domanico, P. L. \& Benkovic, S. J. (1985) Biochemistry 24, 2955-2958.

20. Fukushima, T. \& Nixon, J. (1980) Anal. Biochem. 102, 176- 188 .

21. Lunte, C. E. \& Kissinger, P. T. (1986) Methods Enzymol. $122,300-309$.

22. Archer, M. C. \& Scrimgeour, K. G. (1970) Can. J. Biochem. $48,278-287$.

23. Andersson, K. K., Cox, D. D., Que, L., Jr., Petersson. L., Flatmark, T. \& Haavik, J. (1987) Recueil: J. R. Neth. Chem. Soc. 106,244

24. Andersson, K. K., Cox, D. D., Que, L., Jr., Flatmark, T. \& Haavik, J. (1988) J. Biol. Chem. 263, $18621-18626$.

25. Vigny, A. \& Henry, J. P. (1981) J. Neurochem. 36, $483-$ 489 . 